\title{
Pengembangan Kawasan Industri Ramah Lingkungan Sebagai Upaya Untuk Menjaga Keseimbangan Ekosistem (Studi Kasus di Taman Industri BSB Semarang)
}

\author{
Anif Rizqianti Hariz', Purwanto², Suherman³ \\ ${ }^{1}$ Program Studi Pendidikan Biologi, Fakultas Sains dan Teknologi, UIN Walisongo Semarang \\ 2Program Pascasarjana, Universitas Diponegoro, Semarang \\ ${ }^{3}$ Jurusan Teknik Kimia, Fakultas Teknik, Universitas Diponegoro, Semarang \\ Email: 1anifrizqianti@walisongo.ac.id
}

\begin{abstract}
Abstrak
Kawasan industri merupakan suatu kawasan tempat pemusatan kegiatan industri yang dilengkapi dengan sarana dan prasarana penunjang yang dikembangkan dan dikelola oleh perusahaan kawasan industri. Sumber daya dan energi yang dibutuhkan dalam penyediaan sarana dan prasarana tersebut, serta bahan baku yang digunakan dalam industri, menyebabkan terjadinya eksploitasi berbagai sumber daya alam, yang apabila eksploitasi tersebut tidak terkendali akan dapat menyebabkan terjadinya kerusakan lingkungan. Aktivitas industri memiliki peran dalam pertumbuhan ekonomi, tetapi di sisi lain juga mendorong terjadinya kerusakan lingkungan. Keberadaan kawasan industri dalam sebuah ekosistem tentunya akan menimbulkan dampak dan perubahan pada ekosistem tersebut. Padahal dalam ekosistem sendiri terdapat berbagai macam komponen yang menyusunnya, baik itu komponen biotik maupun abiotik. Untuk itu, muncul sebuah konsep yang disebut konsep industri hijau, yaitu kawasan industri yang ramah lingkungan, sehingga dapat dicapai manfaat lingkungan, ekonomi, dan sosial sebanyak mungkin. Dan tujuan jangka panjang dari konsep ini adalah untuk mempertahankan keseimbangan ekosistem yang menjadi tempat berlangsungnya kegiatan industri pada kawasan industri. Proses pengembangan kawasan industri terus dilakukan agar dapat menjadi kawasan industri hijau. Taman Industri BSB merupakan salah satu kawasan industri di Semarang yang sedang berkembang. Dalam penelitian ini dilihat hal-hal apa saja yang menjadi kekuatan, kelemahan, peluang, dan ancaman dalam pengembangan Taman Industri BSB menjadi kawasan industri hijau. Metode yang digunakan dalam pemilihan strategi adalah analisis SWOT. Hasil penelitian menunjukkan bahwa strategi yang dapat dilakukan pada tahap awal pengembangan adalah melakukan pembelian bahan baku bersama antar industri sejenis dalam kawasan, pengoperasian IPAL kawasan untuk mengolah air limbah secara komunal, dan kerjasama antara industri dalam kawasan dan masyarakat sekitar dengan mengembangkan industri kecil daur ulang.
\end{abstract}

Kata kunci: kawasan industri, ekosistem, analisis SWOT, Taman Industri BSB.

\section{Pendahuluan}

Kawasan industri merupakan kawasan tempat pemusatan kegiatan industri yang dilengkapi dengan sarana dan prasarana penunjang yang dikembangkan dan dikelola oleh perusahaan kawasan industri (Undang-undang Republik Indonesia No. 3 Tahun 2014). Sarana dan prasarana tersebut antara lain akses jalan, penyediaan air bersih dan pengolahan limbah terpadu, jaringan listrik, jaringan telekomunikasi, dan sebagainya. Dalam kawasan industri terjadi berbagai aktivitas industri, yang mana aktivitas ini memiliki peran dalam pertumbuhan ekonomi, tetapi di sisi lain juga mendorong terjadinya kerusakan lingkungan. Kerusakan lingkungan yang dimaksud adalah akibat dari eksploitasi sumber daya alam yang digunakan sebagai sumber energi dan bahan baku dalam kegiatan industri, serta lingkungan sebagai tempat 
pembuangan limbah. Untuk meminimalkan kerusakan lingkungan tersebut, diperlukan suatu konsep yang dapat menyelaraskan antara pertumbuhan ekonomi dan kelestarian lingkungan, yang dikenal dengan industri hijau (green industry). Definisi dari industri hijau adalah industri yang dalam proses produksinya mengutamakan upaya efisiensi dan efektivitas penggunaan sumber daya secara berkelanjutan sehingga mampu menyelaraskan pembangunan industri dengan kelestarian fungsi lingkungan hidup serta dapat memberikan manfaat bagi masyarakat (Undangundang Republik Indonesia No. 3 Tahun 2014). Sedangkan taman industri hijau (green industrial park) adalah kumpulan dari pabrik/industri yang mengaplikasikan teknologi produksi bersih, melakukan pemrosesan terhadap limbah industrinya dan/atau mengurangi emisi gas rumah kaca pada area dimana industri tersebut beroperasi (Fleigh, 2000; Lowe, 2001). Selain itu, terdapat pula konsep eco-industrial park yang merupakan suatu konsep taman industri yang dikembangkan untuk mencapai manfaat lingkungan, ekonomi, dan sosial sebanyak mungkin (Lowe, 2001). Dalam konsep tersebut, terdapat berbagai macam kriteria yang salah satunya adalah produksi bersih. Produksi bersih merupakan model pengelolaan lingkungan yang mengedepankan bagaimana agar setiap kegiatan industri yang dilakukan mempunyai efisiensi yang tinggi sehingga timbulan limbahnya dapat dicegah dan dikurangi (Purwanto, 2005). Dengan penerapan produksi bersih pada industri, maka industri akan diuntungkan baik dari segi biaya produksi maupun lingkungan.

Limbah merupakan hasil samping yang tidak diinginkan dari proses produksi dalam kegiatan industri. Banyak industri yang menganggap limbah sebagai sesuatu yang tidak perlu diperhatikan. Seperti diketahui, semakin banyak produk yang dihasilkan maka limbah yang dihasilkan juga semakin banyak. Dengan banyaknya produk yang dihasilkan, maka dibutuhkan bahan baku dan energi yang lebih banyak pula. Pengelompokan industri dalam suatu kawasan membuat kegiatan pemantauan terhadap sumber energi dan bahan baku yang digunakan, serta limbah yang dihasilkan dan bagaimana pengelolaannya (Hadiwijoyo, 2013). Terdapat 3 jenis sistem aliran energi dan sumber daya, yaitu sistem linier, sistem lingkaran tertutup yang telah ada kerja sama antar komponen dalam ekosistem, dan sistem lingkaran tertutup sempurna yang merepresentasikan kesetimbangan ekologis (Jelinski et al., 1992). Pada tahap awal pengembangan, industri biasanya menggunakan sistem linier, tetapi hal tersebut tidak dapat dilakukan secara terus-menerus, mengingat keterbatasan sumber daya dan daya tampung lingkungan. Sistem industri yang ada saat ini termasuk dalam jenis sistem lingkaran tertutup, yang mana telah dilakukan daur ulang dan penggunaan kembali bahan dan limbah untuk mengurangi input sumber daya dan output limbah. Dalam pengembangan industri, yang dituju adalah tipe sistem lingkaran tertutup sempurna, dimana energi dan limbah digunakan dan didaur ulang secara konstan sehingga tercapai proses yang berkelanjutan.

Taman Industri BSB merupakan salah satu kawasan industri yang terletak di dalam kawasan Bukit Semarang Baru (BSB) City, Kecamatan Mijen, Kota Semarang. Kawasan industri ini memiliki luas 112 ha, yangdi dalamnya terdapat 25 industri yang telah dan akan beroperasi, dengan berbagai macam jenis industri, antara lain industri baterai, mebel, percetakan, dan sebagainya. Untuk menjadi kawasan industri hijau, ada 7 prinsip yang harus diimplementasikan, yaitu integrasi dengan sistem alam, sistem energi, aliran material dan manajemen limbah di seluruh kawasan, sistem penggunaan air, manajemen yang efektif, konstruksi dan rehabilitasi bangunan, serta integrasi dengan masyarakat sekitar (Lowe, 2001). Prinsip yang telah diterapkan 
pada kawasan industri tersebut adalah prinsip integrasi dengan alam dan penggunaan material dan teknologi bangunan yang ramah lingkungan.

\section{Metode}

Metode yang digunakan dalam penelitian ini adalah metode kualitatif dan kuantitatif. Penelitian dilakukan di Taman Industri BSB (Bukit Semarang Baru), Kecamatan Mijen, Kota Semarang. Pengumpulan data dilakukan melalui wawancara kepada pengelola Taman Industri BSB dan warga yang tinggal di sekitar Taman Industri BSB. Hasil yang didapat kemudian dianalisis menggunakan SWOT (strength, weakness, opportunity, threat) beserta strategi pengembangan kawasan industri, dan dipilih strategi mana yang diusulkan untuk diterapkan dalam tahap awal pengembangan. Menyusun indikator-indikator strategis internal (kekuatan dan kelemahan) dan eksternal (peluang dan ancaman) analisis SWOT, kemudian memberikan nilai bobot dan rating pada masingmasing indikator. Nilai bobot diberikan mulai dari 0,0 (tidak penting) hingga 1,0 (sangat penting). Jumlah bobot pada indikator strategis internal dan eksternal tidak melebihi 1,0. Rating diberikan nilai dengan skala 1-3. Pada indikator kekuatan dan peluang, nilai 1 berarti tidak penting, 2 berarti agak penting, 3 berarti penting, dan 4 sangat penting. Sedangkan pada indikator kelemahan dan ancaman, berlaku arti nilai yang sebaliknya (Rangkuti, 2010).

\section{Hasil dan Pembahasan}

Untuk menentukan strategi pengembangan Taman Industri BSB menjadi kawasan industri hijau, dilakukan identifikasi SWOT (strength, weakness, opportunity, threat) terhadap kekuatan dan kelemahan serta peluang dan ancaman yang dimiliki oleh Taman Industri BSB yang didapatkan melalui wawancara dengan pihak terkait dan observasi lapangan pada Tabel 1.

Dari identifikasi faktor kekuatan, kelemahan, peluang, dan hambatan tersebut, dilakukan analisis SWOT untuk kemudian dilakukan penyusunan strategi-strategi yang dapat dilakukan untuk mengembangkan Taman Industri BSB menjadi kawasan industri hijau. Penentuan prioritas strategi dilakukan dengan pemberian bobot dan rating untuk masing-masing faktor internal dan eksternal. Berdasarkan Rangkuti (2010), bobot masingmasing indikator dalam faktor internal dan eksternal diberikan dengan jumlah bobot maksimal adalah 1,0. Penentuan bobot masing-masing indikator dilakukan berdasarkan prioritas pengelola Taman Industri BSB terkait dengan visi dan misi perusahaan. Kemudian setiap bobot yang diberikan dikalikan dengan rating, yang diberikan pada masing-masing indikator berdasarkan hasil wawancara dengan responden, yaitu pengelola Taman Industri BSB, industri-industri, dan masyarakat sekitar. Rating faktor peluang dan kekuatan dengan nilai 1 berarti tidak penting, 2 kurang penting, 3 penting, dan 4 sangat penting untuk pengembangan kawasan industri (Rangkuti, 2010). Pemberian rating untuk faktor ancaman dan kelemahan kebalikan dari faktor peluang dan kekuatan.

Tabel 1. Analisis SWOT pengembangan Taman Industri BSB

\begin{tabular}{|c|c|}
\hline Kekuatan & Kelemahan \\
\hline $\begin{array}{l}\text { 1. Adanya RTH dan peraturan mengenai RTH } \\
\text { dalam kawasan industri. }\end{array}$ & $\begin{array}{l}\text { 1. Belum menggunakan sumber daya terbarukan } \\
\text { sebagai sumber energi. }\end{array}$ \\
\hline $\begin{array}{l}\text { 2. Visi dan misi pengelola kawasan industri untuk } \\
\text { mewujudkan kawasan industri berwawasan } \\
\text { lingkungan. }\end{array}$ & $\begin{array}{l}\text { 2. Sistem penggunaan air bersifat linier. } \\
\text { 3. Belum ada program edukasi dan pelatihan } \\
\text { bagi masyarakat sekitar. }\end{array}$ \\
\hline $\begin{array}{l}\text { 3. Pelibatan masyarakat sekitar sebagai tenaga } \\
\text { kerja. }\end{array}$ & $\begin{array}{l}\text { 4. Belum dilakukan integrasi penggunaan energi } \\
\text { dan pengolahan limbah. }\end{array}$ \\
\hline 4. Penggunaan struktur bangunan yang kuat dan & 5. Belum ada konsep dan kebijakan dari \\
\hline
\end{tabular}




\begin{tabular}{|c|c|}
\hline Kekuatan & Kelemahan \\
\hline $\begin{array}{l}\text { desain hemat energi. } \\
\text { 5. Lokasi kawasan industri yang bebas banjir, } \\
\text { tidak rawan longsor, tidak rawan gempa, dan } \\
\text { tidak di daerah patahan. } \\
\text { 6. Terdapat kavling yang masih kosong untuk } \\
\text { digunakan industri baru yang dapat } \\
\text { menyeimbangkan komposisi industri dalam } \\
\text { kawasan. }\end{array}$ & $\begin{array}{l}\text { pengelola kawasan untuk menyeimbangkan } \\
\text { komposisi industri yang ada dalam kawasan } \\
\text { agar dapat saling memanfaatkan hasil } \\
\text { samping. } \\
\text { 6. Belum terjadi komunikasi antar industri dalam } \\
\text { kawasan untuk berbagi informasi maupun } \\
\text { kerjasama. } \\
\text { 7. Belum tersedia sarana penanggulangan } \\
\text { keadaan darurat bersama. }\end{array}$ \\
\hline Peluang & Ancaman \\
\hline $\begin{array}{l}\text { 1. Peluang bisnis/usaha bagi masyarakat sekitar. } \\
\text { 2. Pertukaran bahan baku dan limbah serta } \\
\text { kerjasama antar industri. } \\
\text { 3. Kecenderungan konsumen menggunakan } \\
\text { produk ramah lingkungan. } \\
\text { 4. IPAL kawasan sedang dalam proses } \\
\text { pembangunan. } \\
\text { 1. Terhubung dengan akses jalan yang baik dan } \\
\text { jalur BRT yang menghubungkan ke pusat kota. }\end{array}$ & $\begin{array}{l}\text { 1. Masyarakat sekitar merasakan peningkatan } \\
\text { suhu lingkungan } \\
\text { 2. Penggunaan air dan energi dalam siklus } \\
\text { membutuhkan teknologi dan tenaga khusus, } \\
\text { serta biaya investasi yang cukup mahal } \\
\text { 3. Kecenderungan pengusaha untuk } \\
\text { mendapatkan keuntungan sebanyak- } \\
\text { banyaknya dengan mengesampingkan aspek } \\
\text { lingkungan } \\
\text { 4. Tingkat pendidikan masyarakat sekitar kurang } \\
\text { memadai }\end{array}$ \\
\hline
\end{tabular}

Tabel 2. Perhitungan faktor eksternal

\begin{tabular}{|c|l|c|c|c|}
\hline No. & \multicolumn{1}{|c|}{ Indikator } & Bobot & Rating & Skor \\
\hline A & Peluang & & & \\
\hline 1 & Peluang bisnis bagi masyarakat sekitar & 0,1 & 3 & 0,3 \\
\hline 2 & Pertukaran bahan baku dan limbah serta kerjasama antar industri & 0,15 & 3 & 0,45 \\
\hline 3 & $\begin{array}{l}\text { Kecenderungan konsumen untuk menggunakan produk yang ramah } \\
\text { lingkungan }\end{array}$ & 0,05 & 2 & 0,1 \\
\hline 4 & IPAL kawasan dalam proses pembangunan & 0,15 & 3 & 0,45 \\
\hline 5 & $\begin{array}{l}\text { Terhubung dengan akses jalan yang baik dan jalur BRT yang } \\
\text { menghubungkan ke pusat kota }\end{array}$ & 0,1 & 3 & 0,3 \\
\hline B & Ancaman & & & \\
\hline 1 & Masyarakat sekitar merasakan peningkatan suhu lingkungan & 0,1 & 2 & 0,2 \\
\hline 2 & $\begin{array}{l}\text { Penggunaan energi dan air dengan siklus tertutup membutuhkan } \\
\text { teknologi dan SDM khusus }\end{array}$ & 0,15 & 2 & 0,3 \\
\hline 3 & $\begin{array}{l}\text { Kecenderungan pengusaha untuk mendapatkan keuntungan } \\
\text { sebanyak-banyaknya dengan mengabaikan aspek lingkungan }\end{array}$ & 0,15 & 2 & 0,3 \\
\hline 4 & Tingkat pendidikan masyarakat sekitar kurang memadai & 0,05 & 2 & 0,1 \\
\hline & \multicolumn{1}{|c|}{ Jumlah } & 1,0 & & \\
\hline
\end{tabular}

Dari Tabel 2 didapatkan bobot dan rating masing-masing indikator untuk mendapatkan skor. Faktor peluang memiliki 5 indikator, sedangkan faktor ancaman memiliki 4 indikator. Skor tertinggi pada faktor peluang didapatkan oleh indikator IPAL kawasan industri dalam proses pembangunan dan indikator pertukaran bahan baku dan limbah serta kerjasama antar industri, hal ini dikarenakan pemberian bobot yang cukup besar yaitu 0,15 dan pemberian rating 3 dimana berarti indikator ini penting. Adanya IPAL terpadu dalam kawasan industri akan sangat membantu dalam hal pengendalian pencemaran lingkungan oleh air limbah industri. Pertukaran bahan baku dan limbah 
serta kerjasama antar industri juga diberi rating 3 yang berarti penting. Untuk menjadi sebuah kawasan industri yang berwawasan lingkungan, perlu terjadi pertukaran bahan bau maupun limbah, atau kerjasama antar industri yang saling menguntungkan. Sedangkan skor terendah pada faktor peluang didapatkan oleh indikator kecenderungan konsumen menggunakan produk yang ramah lingkungan dengan skor 0,1. Bobot yang didapatkan sebesar 0,05 dengan rating 2 yang bermakna kurang penting. Kecenderungan konsumen untuk menggunakan produk yang ramah lingkungan dianggap penting, karena konsumen memegang peranan penting dalam bidang industri. Selain itu, konsumen tipe ini akan selektif dalam memilih produk yang akan digunakannya. Tetapi, pentingnya menggunakan produk yang ramah lingkungan masih belum tenar pada kalangan masyarakat umum, khususnya yang memiliki tingkat pendidikan rendah yang disertai tingkat penghasilan yang rendah pula, sehingga diberikan bobot tidak terlalu besar untuk indikator ini.

Pada faktor ancaman, skor tertinggi didapatkan oleh indikator penggunaan energi dan air dengan siklus tertutup membutuhkan teknologi dan SDM khusus dan indikator kecenderungan pengusaha untuk mendapatkan keuntungan sebanyak-banyaknya dengan mengabaikan aspek lingkungan dengan skor 0,3. Pada indikator penggunaan energi dan air dengan siklus tertutup membutuhkan teknologi dan SDM khusus, diberikan bobot 0,15 dan rating 2, yang berarti penting. Dalam merancang aplikasi teknologi penggunaan air dan energi dalam siklus tertutup beserta SDM-nya memiliki dampak sangat penting terhadap penerapan konsep industri hijau di Taman
Industri BSB. Indikator kecenderungan pengusaha untuk mendapatkan keuntungan sebanyakbanyaknya dengan mengabaikan aspek lingkungan mendapatkan bobot 0,15 dan rating 2, yang berarti sangat penting. Pengusaha yang dimaksud adalah pengusaha/perusahaan yang akan menjadi bagian dari Taman Industri BSB. Peran pengusaha dalam pengendalian pencemaran sangat penting, dimana masih banyak perusahaan yang tidak memasukkan biaya pengelolaan lingkungan ke dalam keuangan internal perusahaan. Dengan peran perusahaan dalam menjaga aspek lingkungan, maka turut membantu dalam penerapan kawasan industri hijau. Skor terendah pada indikator tingkat pendidikan masyarakat sekitar kurang memadai dengan skor 0,1 . Bobot yang diberikan adalah 0,05 dan rating 2 yang berarti penting. Masyarakat yang berpendidikan tinggi masih sedikit, sehingga memperkecil peluang untuk dapat bekerja pada perusahaan yang membutuhkan tenaga kerja dengan tingkat pendidikan yang tinggi. Namun banyak mata pencaharian di bidang lainnya yang dapat diisi, sehingga dalam perhitungan ini mendapat kategori penting.

Jumlah skor pada faktor peluang adalah sebesar 1,6 dan jumlah skor pada faktor ancaman adalah sebesar 0,9. Maka, didapatkan bahwa peluang lebih besar skornya daripada ancaman dengan selisih 0,7. Nilai ini kemudian diplot dalam diagram SWOT pada sumbu Y.

Selanjutnya, diberikan pula bobot dan rating pada masing-masing indikator untuk faktor internal. Pemberian bobot dan rating untuk faktor internal sama dengan faktor eksternal, seperti yang terdapat dalam Tabel 3.

Tabel 3. Perhitungan faktor internal

\begin{tabular}{|c|l|c|c|c|}
\hline No. & \multicolumn{1}{|c|}{ Indikator } & Bobot & Rating & Skor \\
\hline A & Kekuatan & & & \\
\hline 1 & Penyediaan RTH & 0,1 & 3 & 0,3 \\
\hline 2 & $\begin{array}{l}\text { Visi dan misi pengelola untuk mewujudkan kawasan industri yang } \\
\text { berwawasan lingkungan }\end{array}$ & 0,1 & 3 & 0,3 \\
\hline 3 & Pelibatan masyarakat sekitar sebagai pegawai pabrik & 0,05 & 3 & 0,15 \\
\hline
\end{tabular}




\begin{tabular}{|c|c|c|c|c|}
\hline No. & Indikator & Bobot & Rating & Skor \\
\hline 4 & $\begin{array}{l}\text { Penggunaan struktur bangunan yang kuat dan desain bangunan yang } \\
\text { hemat energi }\end{array}$ & 0,1 & 3 & 0,3 \\
\hline 5 & $\begin{array}{l}\text { Lokasi kawasan industri yang bebas banjir, tidak di daerah patahan, } \\
\text { rawan longsor, dan rawan gempa }\end{array}$ & 0,1 & 3 & 0,3 \\
\hline 6 & $\begin{array}{l}\text { Terdapat kavling yang masih kosong untuk digunakan industri baru } \\
\text { yang dapat menyeimbangkan komposisi industri dalam kawasan }\end{array}$ & 0,05 & 2 & 0,1 \\
\hline $\mathbf{B}$ & Kelemahan & & & \\
\hline 1 & $\begin{array}{l}\text { Belum menggunakan sumber daya terbarukan sebagai sumber } \\
\text { energi }\end{array}$ & 0,1 & 2 & 0,2 \\
\hline 2 & Sistem penggunaan air bersifat linier & 0,1 & 2 & 0,2 \\
\hline 3 & $\begin{array}{l}\text { Belum adanya program pelatihan dan edukasi bagi masyarakat } \\
\text { sekitar }\end{array}$ & 0,03 & 3 & 0,09 \\
\hline 4 & $\begin{array}{l}\text { Belum dilakukannya integrasi penggunaan energi dan pengolahan } \\
\text { limbah antar pabrik }\end{array}$ & 0,03 & 2 & 0,06 \\
\hline 5 & $\begin{array}{l}\text { Belum ada konsep dan kebijakan dari pengelola kawasan untuk } \\
\text { menyeimbangkan komposisi industri yang ada dalam kawasan agar } \\
\text { dapat saling memanfaatkan hasil samping }\end{array}$ & 0,07 & 2 & 0,14 \\
\hline 6 & $\begin{array}{l}\text { Belum terjadi komunikasi antar industri dalam kawasan untuk } \\
\text { berbagi informasi maupun kerjasama }\end{array}$ & 0,07 & 2 & 0,14 \\
\hline 7 & Belum tersedia sarana penanggulangan keadaan darurat & 0,1 & 1 & 0,1 \\
\hline \multicolumn{2}{|r|}{ Jumlah } & 1,0 & & \\
\hline
\end{tabular}

Dari Tabel 3 didapatkan masing-masing bobot, rating, dan skor untuk masing-masing indikator. Pada faktor kekuatan, indikator yang mendapatkan skor tertinggi adalah indikator penyediaan RTH, indikator visi-misi pengelola kawasan industri untuk mewujudkan kawasan industri yang berwawasan lingkungan, indikator penggunaan struktur bangunan yang kuat dan desain bangunan yang hemat energi, dan indikator lokasi kawasan industri yang bebas banjir, tidak di daerah patahan, rawan longsor, dan rawan gempa dengan skor masing-masing sebesar 0,3. Kedua indikator tersebut mendapatkan bobot 0,1 dengan rating 3 yang berarti sangat penting. Adanya RTH dalam kawasan industri memiliki peran penting dalam hal menjaga iklim mikro dan menyerap gas rumah kaca yang dihasilkan oleh kegiatan industri serta kegiatan pendukungnya. Selain itu, juga menjaga penyerapan air hujan sehingga air hujan yang turun tidak semuanya mejadi air permukaan. Kemudian, indikator visi-misi pengelola kawasan industri untuk mewujudkan kawasan industri yang berwawasan lingkungan juga memiliki peran penting. Dengan visi dan misi yang sejalan dengan kelestarian lingkungan, maka akan diturunkan dalam bentuk penerapan desain dan kebijakan serta peraturan yang pro lingkungan. Penggunaan struktur bangunan yang kuat dan desain bangunan yang hemat energi sejalan dengan visi dan misi perusahaan. Selain itu, lokasi kawasan industri yang aman juga memiliki peran penting dalam kegiatan pengembangan ke depannya. Sedangkan skor terendah pada faktor kekuatan didapatkan oleh indikator terdapat kavling yang masih kosong untuk digunakan industri baru yang dapat menyeimbangkan komposisi industri dalam kawasan dengan skor sebesar 0,1. Bobot yang diberikan adalah 0,05 dengan rating 2 yang berarti kurang penting. Hal ini terkait dengan kebijakan pengelola kawasan yang belum merencanakan keseimbangan komposisi industri dalam kawasan industrinya.

Pada faktor kelemahan, skor tertinggi didapatkan oleh indikator belum menggunakan sumber daya terbarukan sebagai sumber energi dan indikator sistem penggunaan air bersifat linier dengan skor masing-masing 0,2. Skor ini didapatkan dari perkalian bobot sebesar 0,1 dan rating 2 , yang 
berarti indikator ini dianggap penting. Penggunaan sumber daya yang terbarukan adalah hal penting dalam keberlanjutan kawasan industri karena dalam kegiatan industri membutuhkan sumber daya dalam jumlah yang besar untuk memenuhi kebutuhan pasar, sehingga harus dapat mempertahankan produksinya dengan menggunakan sumber daya yang terbarukan. Air juga termasuk sumber daya yang harus dijaga kelestariannya karena perannya yang penting dalam kegiatan industri, sehingga jika penggunaannya bersifat linier lama kelamaan akan berkurang jumlah air yang bersih sehingga dianggap penting. Indikator yang mendapatkan skor terendah adalah indikator belum dilakukannya integrasi penggunaan energi dan pengolahan limbah antar pabrik dengan skor sebesar 0,06. Indikator belum dilakukannya integrasi penggunaan energi dan pengolahan limbah antar

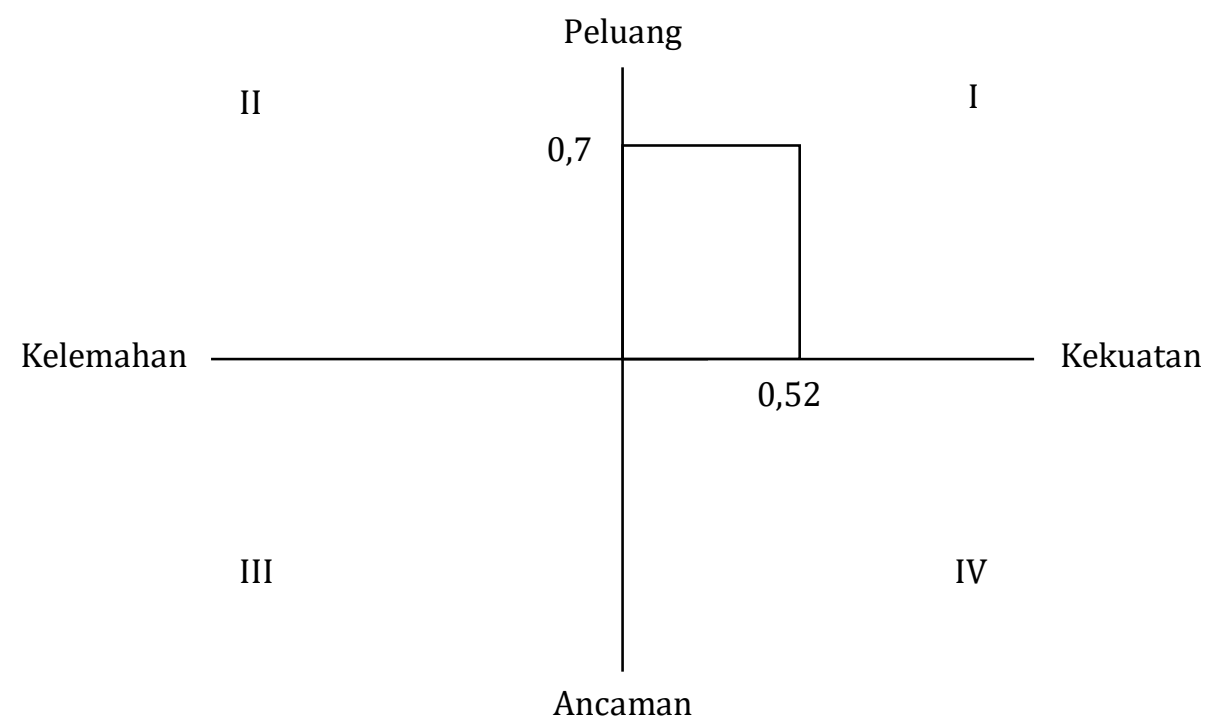

Gambar 1. Diagram Analisis SWOT Taman Industri BSB

Dari Gambar 1 tersebut, kondisi Taman Industri BSB saat ini berada pada kuadran 1, yang mana terdapat peluang dan memiliki kekuatan yang lebih besar daripada kelemahan untuk menjadi kawasan industri hijau. Dalam kondisi tersebut, maka kekuatan-kekuatan yang dimiliki harus pabrik diberikan bobot 0,03 dan rating 2 yang berarti penting. Integrasi penggunaan energi memegang peranan penting dalam penerapan kawasan industri. Dengan penggunaan energi secara terintegrasi, berarti penghematan dalam penggunaan energi yang akan meminimalkan penggunaan sumber daya alam sebagai sumber energi.

Jumlah skor pada faktor kekuatan adalah sebesar 1,45 dan jumlah skor pada faktor kelemahan adalah sebesar 0,93. Maka, didapatkan bahwa kekuatan memiliki skor yang lebih besar daripada kelemahan dengan selisih 0,52 . Nilai ini diplotkan dalam diagram SWOT pada sumbu X.

Hasil perhitungan peluang-ancaman dan kekuatan-kelemahan pada Tabel 2 dan Tabel 3 kemudian diplot pada diagram SWOT pada Gambar 1 berikut ini. 
1) Melakukan pembelian bahan baku bersama antar industri sejenis dalam kawasan.

2) Pengoperasian IPAL kawasan untuk mengolah air limbah secara komunal.

3) Kerjasama antara industri dalam kawasan dan masyarakat sekitar dengan mengembangkan industri kecil daur ulang.

b. Strategi W-O (kelemahan-peluang)

1) Merealisasikan pengoperasian IPAL yang memiliki kualitas efluen yang setara dengan air baku agar dapat didaur ulang.

2) Melakukan program edukasi dan pelatihan bagi masyarakat sekitar.

c. Strategi S-T (kekuatan-ancaman)

1) Melakukan penanaman tumbuhan yang mempunyai tajuk yang lebar dan dapat menyerap gas rumah kaca.

2) Pemberian sanksi bagi industri yang tidak mematuhi peraturan penyediaan RTH.

3) Melakukan kegiatan pemantauan lingkungan secara rutin.

d. Strategi W-T (kelemahan-ancaman)

1) Mengembangkan program CSR bagi masyarakat sekitar, atau memberikan beasiswa pada anak usia sekolah masyarakat sekitar yang terseleksi, agar dapat berpendidikan tinggi dan menjadi SDM berkualitas untuk direkrut menjadi tenaga ahli.

2) Pemberian sanksi kepada pengusaha/ industri yang tidak pro lingkungan.

3) Penyediaan unit penanggulangan keadaan darurat

Berdasarkan analisis SWOT, strategi S-O atau strategi kekuatan-peluang yang dapat dilakukan pada tahap awal pengembangan Taman Industri BSB yaitu melakukan pembelian bahan baku bersama antar industri sejenis dalam kawasan, pengoperasian IPAL kawasan untuk mengolah air limbah secara komunal, dan kerjasama antara industri dalam kawasan dan masyarakat sekitar dengan mengembangkan industri kecil daur ulang.

\section{Kesimpulan}

Strategi pengembangan kawasan industri hijau di Taman Industri BSB yang diusulkan yaitu melakukan pembelian bahan baku bersama antar industri sejenis dalam kawasan, pengoperasian IPAL kawasan untuk mengolah air limbah secara komunal, dan kerjasama antara industri dalam kawasan dan masyarakat sekitar dengan mengembangkan industri kecil daur ulang. Hal ini diharapkan dapat menjaga keberlangsungan ekosistem di Taman Industri BSB Semarang.

\section{Daftar Pustaka}

Fleig, Anja-Katrin. 2000. Eco-Industrial Parks, A Strategy towards Industrial Ecology in Developing and Newly Industrialised Country. Deutshce Gesellschaft fur Technische Zusammenarbeit (GTZ) GmbH. Eschborn.

Hadiwijoyo, R. 2014. Model Pengembangan Kawasan Industri Berwawasan Lingkungan dengan Tinjauan Penggunaan Energi di Kawasan Industri Krakatau Cilegon. Disertasi Program Doktor Ilmu Lingkungan, Universitas Diponegoro.

Jelinski, L. W., T. E. Graedel, R. A. Laudise, D. W. McCall, dan C. K. Patel. 1992. Industrial ecology: concepts and approaches. Proceedings of the National Academy of Sciences, 89 (3), 793-797.Lowe, Ernest A. 2001. Eco-industrial Park Handbook for Asian Developing Countries. www.indigodev.com diunduh pada tanggal 26 Januari 2015.

Lowe, Ernest A. 2001. Eco-industrial Park Handbook for Asian Developing Countries. www.indigodev.com diunduh pada tanggal 26 Januari 2015.

Purwanto. 2005. Penerapan Produksi Bersih di Kawasan Industri. Seminar Penerapan Program Produksi Bersih Dalam mendorong Terciptanya Kawasan Eco-industrial di Indonesia. Jakarta.

Rangkuti, Freddy. 2010. Analisis SWOT: Teknik Membedah Kasus Bisnis. PT. Gramedia Pustaka Utama. Jakarta.

Undang-undang Republik Indonesia Nomor 3 Tahun 2014 tentang Perindustrian. 